\title{
LA ESPIRITUALIDAD DE HIPÓLITA DE ROCABERTÍ Y LA CONSTRUCCIÓN DE SU IMAGEN EN EL SIGLO XVII *
}

POR

\author{
Rosa María Alabrús IgLesias \\ Universitat Abat Oliba CEU
}

\begin{abstract}
RESUMEN
El artículo analiza las características objetivas de la espiritualidad de Hipólita de Rocabertí, manifestadas en su Autobiografía. Se contrasta la religiosidad de la monja dominica con los esfuerzos de construcción de su imagen en el siglo XVII: la glosa del jesuita Jaume Puig, la biografía escrita por Antonio de Lorea y la operación de promoción a la beatificación que desarrolló su sobrino Juan Tomás de Rocabertí. Se estudian las causas de su proceso de beatificación fallida.
\end{abstract}

Palabras Clave: Espiritualidad - Hipólita de Rocabertí - Religiosidad - Monja dominica -Imagen- Siglo XVII- Proceso de beatificación.

\section{THE SPIRITUALITY OF HIPÓLITA DE ROCABERTÍ AND CONSTRUCTION OF YOUR PICTURE IN THE XVII CENTURY}

\begin{abstract}
The article analyzes the objective characteristics of spirituality of Hipólita de Rocabertí expressed in his Autobiography. It contrast the religiosity of the Dominican nun with the construction of her image in the Seventeenth century: the gloss of the jesuit Jaume Puig, the biography written by Antonio de Lorea and the promotion and operation of the beatification developeds for his nephew Juan Tomás Rocabertí. There are studied the reasons of his process of unsuccessful beatification.
\end{abstract}

\footnotetext{
* Este artículo se inserta dentro del proyecto de investigación «Memoria y cultura religiosa en el mundo hispánico. 1500-1835». Universidad Autónoma de Barcelona y Ministerio de Economía y Competitividad (2012-14) con referencia HAR 2011-28732-CO3-01/HIST.
} 
KEY WORDS: Spirituality - Hipólita de Rocabertí - Religiosity - Dominican nun - Image - Seventeenth century - Beatification process.

$\begin{array}{ll}\text { Recibido/Received } & 15-09-2013 \\ \text { Aceptado/Accepted } & 15-09-2014\end{array}$

Conocemos bien hoy los principales rasgos biográficos de la célebre monja dominica catalana Hipólita de Jesús, especialmente gracias a las precisiones que ha hecho Laia de Ahumada. Hipólita de Jesús, que firmó así sus escritos religiosos y privados o Hipólita de Rocabertí y Soler, que otorgó este nombre a sus escritos públicos y notariales, nació según el proceso de su beatificación el 22 de enero de 1553, aunque la fecha sigue siendo discutida. ${ }^{1}$

Era hija natural del vizconde de Rocabertí, Francesc Dalmau de Rocabertí y de Çarriera (que murió en 1592). Su madre, de apellido Soler, nos es desconocida. El confesor Puig le atribuyó llamarse a sí misma «hija del pecado». ${ }^{2} \mathrm{Su}$ padre se casó en 1558, siendo ella niña, con Elionora de Boixadors con la que tuvo doce hijos. Hipólita fue criada posiblemente por una presunta amiga de su madre, Ángela Jerónima Poch Codina, la Corregona, que vivía en la calle Montcada de Barcelona y que cuando enviudó entró en el monasterio de Los Ángeles. Es varias veces citada en la correspondencia de Hipólita, que escribió de ella: «De la mia mare la senyora Corregona, perquè al fi des de la mamella me à criada i portada sobre la sua spatla, vestint i colgant-me tans anys, i tantas caritats com me à fet que seria jo pijor que tigre ni fera cruel que no la amàs com si ella me agués parida pròpiament mare». ${ }^{3}$

Hipólita ingresó, según su propia autobiografía, en el monasterio de los Ángeles cuando tendría diez años, profesó a los dieciséis años y murió el 6 de agosto de 1624. En el convento fue maestra de novicias durante treinta años. Fue también subpriora, pero nunca llegó a priora porque rechazó siempre esta posibilidad. Se le ofreció participar en la fundación del monasterio de Perpiñán, a lo que también renunció para dedicarse en cuerpo y alma a la escritura. ${ }^{4}$

\footnotetext{
${ }^{1}$ Ahumada, L. de. 2013. «Hipólita de Jesús. Biografía y bibliografía» en R. Ma. Alabrús (ed.): La vida cotidiana y la sociabilidad de los dominicos: 139. Sant Cugat: Editorial Arpegio. Ahumada sostiene la tesis de que Hipólita nació en el año 1551. El cronista A. de Lorea defendió que la dominica había nacido en 1549; 2011. «La carta privada a l'època moderna: un epistolari conventual femení inèdit». Revista Manuscrits, 29. UAB: 51-64

2 1624. Sermón que predicó el padre Jaime Puig rector de la Compañía de Jesús en las honras que hizo el monasterio de Nuestra Señora de los Ángeles a la Venerable sor Hipólita de Rocabertí y Soler: 4. Barcelona

${ }^{3}$ Ahumada, L. de. 2013: 139

${ }^{4}$ BUB (Biblioteca Universitaria de Barcelona). 1660. Rocabertí, H. de. 1660. La explicación de la Regla de San Agustín y otros varios tratados espirituales en Tomo III de las obras espirituales de la Venerable: 1. Valencia.
} 
Desarrolló actividades como reformadora, de 1586 a 1591, en el convento de agustinas de Santa María de las Magdalenas de Barcelona. No fue feliz en esta labor y en su epistolario reivindicó a su priora, en ese momento Beatriz de Josa, volver a los Ángeles para retornar a la vida más retirada que tradicionalmente había llevado. Hipólita es claramente admiradora de los carmelitas y se refiere con frecuencia al convento de la Inmaculada, primer monasterio descalzo de Barcelona, en cuya fundación colaboró su prima, Estefanía de Rocabertí. La familia fue eje permanente en la vida de Hipólita. Tuvo siempre estrecha relación con sus primas, Estefanía de Rocabertí, carmelita descalza en el monasterio de la Inmaculada, muy influida por los jesuitas del Colegio de Belén, y Emerenciana Rossell, de su propio convento, así como con su tía Jerónima de Rocabertí. Estefanía fue especialmente valorada por Hipólita que escribió una glosa de ella tras su muerte, en $1608 .^{5}$

Hasta aquí los datos biográficos básicos. La personalidad de Hipólita es extraordinariamente compleja y el análisis de esa complejidad constituye el principal objeto de este artículo. Los juicios de valor que se han hecho de la monja dominicana no han tenido en cuenta la necesidad de diferenciar la realidad objetiva que ella vivió en el marco de la generación siguiente a la de Teresa de Jesús, con la propia visión que la monja tuvo de sí misma y el proceso de construcción de su imagen que empieza por la glosa necrológica de su confesor, Jaume Puig, tras su muerte en 1624 y acaba con los decretos de prohibición inquisitorial que sufren algunas obras de la monja dominicana de 1687 a 1693.

Una trayectoria polémica de ascenso y decadencia de la imagen de Hipólita, desde el mismo momento de su muerte. Ascenso y decadencia que estarán en función de factores coyunturales históricos y políticos de la España del siglo XVII y de la valoración de la espiritualidad religiosa que la propia Iglesia va teniendo, a lo largo del tiempo, con la confrontación entre dominicos y jesuitas como escenario de fondo.

\section{LA REALIDAD Y LA VISIÓN AUTOBIOGRÁFICA DE HIPÓLITA}

Nunca se ha incidido suficientemente en el contexto histórico en el que vivió Hipólita, una coyuntura ciertamente trascendental que puede inscribirse en lo que Pierre Vilar llamó El tiempo del Quijote: decadencia del Imperio que fue,

${ }^{5}$ 1608. Relación hecha por la madre sor Hipòlita de Jesús subpriora del convento de religiosas dominicas de nuestra señora de los Ángeles, a la muerte de Estefanía de Rocabertí. Barcelona; Vid. «Y veinte y tres exemplares vidas que dexo escrito de su mano la V. M. Hipólita de Jesús» en Busquets Matoses, J. 1684. Las cinco piedras de David. Valencia; Poutrin, I. 1995. Le voile et la plume. Autobiographie et sainteté femenine dans l'Espagne moderne : 36-37. Madrid: Bibliothèque de la Casa de Velázquez. 
con toda su estela de nostalgias y arbitrios o hipotéticas alternativas al triste mundo vivido. Aun dentro del convento y con un régimen vital de escasa comunicación exterior, Hipólita no debió quedar absolutamente al margen de aquel momento político de transición del reinado de Felipe II a Felipe III. Aunque no lo cita en su autobiografía, en su proceso de beatificación se alude a que Hipólita recibía frecuentes visitas de la nobleza catalana (en especial del conde de Savallà). No faltaron algunas reflexiones negativas de la dominica respecto a la sociedad que estaba viviendo: ${ }^{6}$

«La locura tan manifiesta de los hombres, que por intereses de dinero negro van tan largos caminos en peligro de ladrones (...) ponen en peligro sus vidas, todo lo prueban por sacar dinero y lo peor es, que muchas veces les salen sus esperanzas en vano y la ganancia de las virtudes, el cumplir bien cumplida la ley de Dios, tan cojeando, con tanta pereza, que es vergüenza, que alguna no parece, que más nos preciamos de cristianos solo en el nombre, más que en los hechos y obras (...). Pues vemos que en las repúblicas tanto reina el vicio, las disensiones, iras, venganzas, envidias, todo es comer, beber, galas, saraos y comedias y cuando se anda por la calle allá se maldice aquí se jura el nombre de Dios (bien dice David). Día y noche veo rodeada la ciudad de iniquidad y maldad y el trabajo y desasosiego en medio de ella y una de las causas de tantos pecados es por la injusticia y nunca veréis faltar en ella la usura y el engaño, sus plazas llenas las hallareis de tráfagos, engaños y mentiras, no tienen verdad, ni fidelidad unos con otros y cómo abunda la maldad, la causa porque se ha resfriado la caridad, y así solo el que preservare en guardarse de estos males y se ocupare con toda vigilancia en guardar la ley de Dios».

Le preocupaban las relaciones entre eclesiásticos y seglares.

Llega a rogar junto a santa Eulalia por «la ciudad de Barcelona que su divina piedad se apiadase de ella, quitando los vicios y los pecados y plantase en ella su santo temor y amor y las demás virtudes y esto con gran eficacia (...). Esta ciudad a la paz y a la unión parece difunta y muerta (...). Haced que pueda más vuestra infinita misericordia que nuestras maldades y desconocimiento». ${ }^{7}$

Hipólita vivió de lleno el impacto de la reforma católica postridentina, el viraje del rey Felipe II hacia la impermeabilización y el fracaso de las apuestas por la tolerancia ideológica. Pese a los muchos nexos comparativos que, con toda lógica, se han hecho de Teresa de Jesús y de Hipólita de Rocabertí, a ambas les separó, aparte de otros factores, el marco histórico en el que crecieron. Teresa pudo vivir las ilusiones que generó el imperio de Carlos V y su obra se inserta en lo que se ha llamado «la herencia comunera». La generación de Hipólita es la de la crisis de los ideales: el fin del modelo cortesano de Baltasar de Castiglione,

\footnotetext{
${ }^{6}$ BUB. Rocabertí, J. T. de (ed). 1679. La Venerable Madre Hipólita de Jesús y Rocabertí: 88 y 253. Valencia: Imprenta Vicente Cabrera.

${ }^{7}$ Ibídem: 247 y 252

Hispania Sacra, LXVII

135, enero-junio 2015, 219-245, ISSN: 0018-215X, doi: 10.3989/hs.2015.006
} 
de la correlación letras-armas, de la identificación Iglesia-Estado, el descubrimiento de la corrupción y el relativismo moral, la cultura del parvenu, el reino de la picaresca, el triunfo de la ética de la necesidad sobre la ética de los principios. A escala catalana, vivió, aunque de lejos, el bandolerismo catalán y el progresivo asentamiento en Barcelona de las élites nobiliarias, la escalada de los «ciutadans honrats» y el choque con la vieja nobleza de sangre, el cambio de valores del honor-limpieza de sangre al honor-opinión, la proyección hacia la nostalgia de la clase social a la que ella pertenecía. ${ }^{8}$

La crisis, Hipólita, la proyectó hacia su propio viaje interior, hacia el intimismo, la soledad, el recogimiento, un viaje siempre de la mano de sus confesores. Los directores de conciencia de Hipólita fueron dos dominicos: Ramón Samsó y el Dr. Broquetes y los jesuitas: Lluís Vidal y Jaume Puig. También la aconsejó, aunque no fue su confesor, el dominico Pedro Guasc. Samsó fue maestro de novicios del convento de Santa Catalina de Barcelona. Tuvo que luchar con Hipólita, para intentar combatir su fijación por el ayuno y los cilicios. La monja sufría graves problemas de estómago que le impedían aplicar los rígidos ayunos que ella misma se imponía. El confesor la consolaba recordándole que las «penitencias, ayunos y rigores eran hijos que engendraba la voluntad y cuando estos por justas razones no pueden ponerse en execución, deve el alma contentarlo con temor a Dios, unido a sí, siguiendo su divina voluntad». ${ }^{9}$ El doctor Broquetes, catedrático en la Universidad y natural de la Seo de Urgell, que le sustituyó, estuvo poco tiempo como confesor. Aunque Hipólita siguió teniendo buena relación con el primer confesor, Ramón Samsó, al que escribía en catalán, pidiéndole que le diese fuerza en sus oraciones, pasó a tener confesores jesuitas. Vidal lo fue durante seis años y escribió una declaración muy positiva de ella en el proceso de canonización, en el que la compara a Santa Teresa. Jaume Puig, fue un jesuita profesor de Teología en Barcelona, rector del Colegio de Belén y viceprovincial de Cataluña, con buenas relaciones con los franceses en los años de separación hasta su muerte en 1646 y autor del Sermón funerario a la muerte de Hipólita, el 6 de agosto de 1624. Como confesor, Hipólita rechazó a un franciscano diciéndole que «en el tiempo de hablar con ella, lo gastase en oración a la madre de Dios en quién hallaría, sin comparación mayor, consuelo para su alma «. Ello le supuso un conflicto con la priora Angélica Casador. Esta le recomendó a varios padres espirituales: un jerónimo (que después se fue a Castilla) y un predicador viejo del que no sabemos la orden a la que pertenecía. Los jesuitas le impusieron la prohibición de llevar la faja de cilicio que se ponía.

\footnotetext{
${ }^{8}$ Vilar, P. 1964. «El tiempo del Quijote» en Crecimiento y desarrollo: 431-449. Barcelona : Ariel; Feros, A. y Gelabert, J. (dirs). 2004: España en tiempos del Quijote. Madrid: Ed. Asociación de Estudios de Ciencias Sociales y Humanidades.

${ }^{9}$ BUB. Rocabertí, J. T. de (ed). 1679. La Venerable ...: 10
} 
En el proceso de beatificación se cita también como confesor al padre Comes. En cualquier caso siempre reivindicó para sí confesores doctos. ${ }^{10}$

La autobiografía fue un género muy cultivado por las monjas y sobre todo a partir de la Vida de Teresa de Jesús. M. Serrano y Sanz nos aporta una abundante relación de autobiografías de monjas entre las que destacan las carmelitas. ${ }^{11}$ Hipólita escribió su autobiografía de 1604 a 1615, con más edad que con la que escribió Teresa su Vida. Ella la escribió entre los 51 y 54 años y Teresa entre los 47 y los 50. La autobiografía nació porque el confesor Samsó la instó a que «escribiese todos los sucesos de su vida, pareciéndole que menos inconveniente sería el que esta venerable madre tuviere mortificación en escribirlos que el que careciese la Iglesia de este tesoro». ${ }^{12}$ Escribió cinco capítulos narrando sus defectos y pecados. A partir del quinto capítulo, el propio confesor le recomendó lo hiciese en tercera persona. Hipólita aplicaría casi siempre ese criterio en sus obras. Escribiría, de cinco en cinco, cuadernos que entregaba al confesor. Era un secreto compartido entre ella, su confesor y la priora. ${ }^{13}$

La autobiografía manuscrita es discontinua, dispersa en cinco volúmenes y con letra muy difícil. Hubo propuesta de edición en 1615, cuando vivía Hipólita, justamente en el momento que se beatificó a Santa Teresa. No llegó a prosperar la idea. En 1672 el notario de Barcelona Ramón Vilana certificó que la autobiografía de Hipólita titulada La vida de la madre sor Hipólita de Rocabertí. Mercedes que Dios le hizo era auténtica. En 1679 su sobrino Juan Tomás de Rocabertí preparó una edición de la misma. Está por hacer un estudio comparativo exhaustivo de la versión manuscrita e impresa. A mi juicio no hay novedades significativas en la obra editada. Lo que sí que hay es un discurso más orgánico y coherente que el del manuscrito..$^{14}$

${ }^{10}$ Ibídem: 6; AGOP (Archivo General de la Orden de Predicadores. Santa Sabina, Roma). Signatura: X. 1377/c. 1671. Proceso de beatificación de Roma: 157.

${ }^{11}$ Serrano y Sanz, M. 1975. Apuntes para una biblioteca de escritoras españolas desde 1401 a 1833. Madrid: Atlas, 2 vols, reed.; Gras Casanovas, Ma. M. 2013. «Familia y clausura. El monasterio de nuestra señora de los Ángeles y Pie de la Cruz de Barcelona (1485-1750)» en R. Ma. Alabrús: La vida cotidiana y la sociabilidad de los dominicos: 117-148. Sant Cugat: Editorial Arpegio; Vid. Gras Casanovas, Ma. M. 2013. «L'escriptura en el Carmel descalç femení: la província de Sant Josep de Catalunya (1588-1835)», Scripta, Revista internacional de literatura i cultura medieval i moderna 1: 302-322. Universitat de València.

${ }^{12}$ BUB. Rocabertí, J. T. de (ed). 1679. La Venerable...: 6-7

${ }^{13}$ Ibídem: 184-185. También Teresa de Jesús escribió su vida por imposición: «Me han mandado y dado larga licencia para que escriba el modo de oración y las mercedes que el Señor me ha hecho, me la dieron para que muy por menudo y con claridad dijera mis grandes pecados y mi ruin vida»(Libro de la vida. Introducción).

${ }^{14}$ La autobiografía manuscrita original está en el Archivo del Monasterio de los Ángeles en Sant Cugat (Barcelona). Se cita el intento de edición de 1615 en una nota añadida al segundo libro de la autobiografía que se encuentra en el citado Archivo. En la portada de este manuscrito, inventariado como libro 2, consta que en realidad se trataba del cuarto libro de la Vida y mercedes de sor Hipólita 
La autobiografía refleja una religiosidad plenamente ortodoxa. El miedo a la herejía a través de la permanente dependencia intelectual de su confesor fue en ella una constante. Su radicalidad contra los herejes está fuera de duda: ${ }^{15}$

«Pues hemos dicho algo del lenguaje que se tiene en el cielo, digan también algo de triste lenguaje que tienen en el infierno, en particular los desdichados Herejes, Calvinistas, Hugonotes, Moros y Judíos y todos los otros enemigos de Dios, miembros apartados de la Santa Madre Iglesia, desobedientes a ella y rebeldes y así no son dignos de participar de sus tesoros, ni son hijos, ni miembros de ella, sino miembros e hijos de Satanás»

Es especialmente crítica con los judios ${ }^{16}$ :

«Vayan fuera los Herejes, Calvinistas, Judíos, Hugonotes y todos los enemigos de la Verdad, que niegan la igualdad de las divinas personas. Los judíos dicen que no hay sino una persona, la del Padre y un solo Dios, como si nosotros creyésemos en tres Dioses, no creyendo los Cristianos más que solo uno, trino en personas y uno en esencia y substancia y así los desdichados y ciegos Judíos niegan el Verbo divino y el Espíritu Santo: no me maravillo de que no conozca al unigénito Hijo de Dios nuestro Salvador Jesucristo que pues en su santísima pasión le pusieron un velo andrajoso, con el cual cubrieron aquel divino rostro.»

Pese al constante ejercicio de recordar y subrayar sus limitaciones, Hipólita demuestra conocer muy bien el latín, las Sagradas Escrituras y un dominio absoluto de la Patrística antigua y medieval: San Pablo, San Agustín, Dionisio el Aeropagita, San Jerónimo y Santo Tomás. En sus Comentarios de San Pablo fueron sus referentes más invocados.

Solo otra monja de su tiempo, Luisa de Carvajal y Mendoza, demostró tener tan buen conocimiento del latín. Desde luego, Hipólita fue muy agustiniana. En su obra Explicación de la Regla de nuestro gran padre y patriarca San Agustín desarrolla en 21 capítulos los principios agustinianos: el amor a Dios sobre todas las cosas, la venida al mundo de Dios «para poner paz y reunión y para que la guardásemos con toda solicitud y cuidado pues ella basta para tener vida quieta y pacífica», la reivindicación de la «sacra unión de todos los creyentes», de la caridad, de la pobreza, la recta intención, la oración penitencia y mortificaciones

que se estaba imprimiendo. Cuando cito la autobiografía lo hago refiriéndome a la edición de 1679 ordenada por el sobrino Rocabertí y solo aludiré al manuscrito cuando considere que la idea reflejada no está en la edición impresa.

${ }^{15}$ Archivo del Monasterio de los Ángeles de San Cugat (AMA). Rocabertí, J. T. de (ed.) 1679. La Venerable Madre Hipólita de Jesús y Rocabertí: 23. Valencia: Imprenta Francisco Mestre

${ }^{16}$ Ibídem: 328. 
y de la discreción en el vestir y el rechazo al «mirar con afición» y a hablar largamente. ${ }^{17}$

La humildad fue el principio de todo su discurso religioso. Una especie de autonegación de sus capacidades expresada, desde el rechazo al cargo de priora, a la valoración de su propia obra. Destaca en ella la perseverante exaltación del sacrificio en todas sus manifestaciones: ayuno, cilicios, soledad, autocontrol disciplinario en el hablar, el vestir, el dormir... En la autobiografía queda clara la frágil salud de Hipólita («A pesar de los medicamentos que le dieron nunca pudieron curarla») y son constantes las relaciones de sus sufrimientos y dolores: «Hallándose con un dolor de cabeza tan grande que le parecía que hasta en el ojo le hincaban un clavo». Pese a su enfermedad se sometió a una disciplina férrea: ${ }^{18}$

«Domad, castigad, sujetad vuestra carne, con ayunos y abstinencia de comer y beber cuando pudieran soportarse y sufrir las fuerzas corporales, sobre este paso de la Regla, bien será nos acordemos de lo que dice san Pablo (...) Castigo de mi cuerpo y le vuelvo a la razón y servidumbre de Dios, peleando y venciendo sus pasiones y apetitos (...).

Hacía ayunos a pan y agua, sin otras penitencias en dormir sobre tablas. Esto no duró más de 5 o 6 años. Pero la calentura y la grande flaqueza del estómago, duró unos 30 años y el no poder seguir todo el rigor que mandan las constituciones: solo me ha quedado la cabeza sin dolor, ni flaqueza, con bastantes fuerzas, gloria sea siempre dada a Dios que por ello puedo seguir al coro sin faltar y sin falta de puntualidad gracias al Padre Santo Domingo (...). A imitación del padre Santo Domingo quiso quedar sin lecho y aun sin celda y dormía sobre un madero tan estrecho, que con dificultad se podía acostar en él y por almohada (...) un poco de madero duro en la cabeza»

Su rigor en el sacrificio le llevó a reflejar auténtica ansiedad de martirio con vocación misional: ${ }^{19}$

«Y si no llevamos el Espíritu Santo de los Santos Apóstoles y de nuestro Padre Santo Domingo, que así como el ciervo desea las fuentes de las aguas, así deseaba el santo martirio y puesto entre los herejes con toda libertad y espíritu les decía que el mayor contento, que le podrían hacer era quitarle la vida y todos los miembros de su cuerpo (...). Solo ruego a los Prelados mayores, que tienen autoridad de enviar Religiosos a tierras remotas y bárbaras que envíen a los mejores, que si de veras lo encomiendan a Dios, hallarán buenos sujetos para enviar a predicar y que harán mucho fruto en las almas».

\footnotetext{
${ }_{17}$ 1660. Tomo III de las Obras espirituales de la Venerable madre Hipólita de Jesús y Rocabertí. Contiene la explicación de la Regla de San Agustín. Valencia

${ }^{18}$ AMA. Rocabertí, J. T. de (ed.). 1679. La Venerable...:15-16 y 215-216.

${ }^{19}$ Ibídem: 239-240.
} 
No hay que olvidar que, en sus últimos años de vida, la problemática de las visiones y martirios en Japón estaría muy presente en el pensamiento dominicano. ${ }^{20}$

Ante los moriscos refleja la misma ansiedad martirial: ${ }^{21}$

«Las Monjas alteradas y temerosas pensaban que los Moriscos entrarían en el Monasterio y las matarían: pero esta religiosa creyendo lo mismo, que las otras, no temió, ni se turbó de nada, sino que estaba muy alegre y gran gozo. Preguntóle otra religiosa ¿Como estaba tan alegre viendo tanto alboroto? Respondió no tengo muy grande causa de estar alegre, pues tantos años ha, que deseo morir por la fe de mi Sr. Jesucristo como santa Rosa»

Detrás del rigor con ella misma había una permanente conciencia de pecado que le generaban la melancolía y el llanto que le acompañaron a lo largo de su vida: «No podía dormir sin parar de llorar y las noches le parecían cada una un año». Siempre con el presunto estigma de los pecados de juventud, de la amenaza de las tentaciones del demonio:

«Siendo moza de 20 años, poco más o menos, en la cual edad es en la que el demonio molesta con más recias tentaciones contra la honestidad, el cual no la perdonó, sino que le dio sus trances amargos».22

Las inquietudes y angustias de Hipólita las resolvió a través de la oración mental y la lectura de la Biblia. Advertía a las demás religiosas que «si quieren vivir consoladas en sus monasterios que se den de veras a la oración mental». Ella reivindica la oración mental para todos, al menos, dos veces al día. Insiste «en que se hallará esta alma en el santísimo misterio de la inefable Trinidad no por discursos sino por incendio de la mente (...) por manifestación divina, secreta y soberana». ${ }^{23}$ Aunque constantemente le pide al confesor que «la corrija, reprenda y enmiende no solo en lo que escribe, sino en todas mis obras, palabras y pensamientos «, reconoce que confesaba con tanta brevedad que «nunca de ordinario se detenía con el confesor, porque en la oración y en la Santa y Divina Escritura hallaba mejor remedio para todas sus tentaciones (...) No quiero dete-

\footnotetext{
${ }^{20}$ Alabrús, R. Ma. 2013: «Misiones en Japón. Las órdenes religiosas ante los martirios en los siglos XVI y XVII» en R. Ma. Alabrús (ed): La vida cotidiana y la sociabilidad de los dominicos: 237-262. Sant Cugat: Editorial Arpegio

${ }^{21}$ AMA. Rocabertí, J. T. de. (ed.). 1679. La Venerable ...: 294.

${ }^{22}$ Ibídem: 145.

${ }^{23}$ Citado por Giordano, L. 2011. «La Contrarreforma y sus críticos. Biblia y oración mental en Hipólita de Rocabertí» en R. Ma. Alabrús: Tradición y modernidad. El pensamiento de los dominicos en la Corona de Aragón en los siglos xVII y XVIII: 43-44. Madrid: Silex; Teresa de Jesús había definido la oración mental: «No es otra cosa sino de tratar de amistad, estando muchas veces tratando a solas con quién sabemos nos ama». Vid. 1951. Obras completas de Teresa de Jesús I, Vida: 638. Cap 8, 5. Madrid.
} 
nerme con el confesor pues el camino que me lleva a Dios es leer y orar en soledad (...) En la oración y lección me parece lo hallo todo». ${ }^{24}$

Oración y lección. Hipólita conjugó siempre la oración mental y la discursiva o vocal. Ciertamente, en su mística primó la noción de mercedes y dones recibidos pero sin desdeñar el conocimiento. Hipólita vivió la polémica $D e$ auxiliis entre confesores jesuitas y dominicos. La formación teológica recibida procedía de las dos órdenes. El conflicto representado por el jesuita Molina y el dominico Báñez, se trasladó a Roma, pero ni el papa Clemente VIII ni Paulo V se decidieron a pronunciarse al respecto a principios del siglo XVII. Se imponía la prudencia. Hipólita lo fue. Su apelación al referente eclesiástico siempre flota en sus obras: «Todo lo contenido en este libro lo sujeto a la Iglesia romana y a los que en ella ha puesto por jueces, censores y procuradores. Lo que ellos aprueben, apruebo»..$^{25}$

La posición equilibrada de Hipólita respecto a la gracia se ve bien en De los sagrados huesos de Cristo. En esta obra cita un párrafo de la carta del apóstol San Pablo a los Efesios en el que afirma que los merecimientos humanos no podían por ellos solo salvar al cristiano. Son los méritos de Cristo los que avalan la promoción a los cielos. En Templo del Espíritu Santo subraya que la busca del Señor no se puede producir «sin su particular auxilio y favor». En la misma obra invoca a san Pablo para subrayar que «somos hijos de Dios por gracia» ${ }^{26}$

Pero al mismo tiempo atribuye a San Pablo que la «fe sin obras es muerta». Hipólita apelando a Santo Tomás de Aquino, defiende la práctica de las virtudes como medio de perfección espiritual. La búsqueda del equilibrio entre la doctrina de la gracia y los méritos es evidente. Le interesó mucho la dualidad Marta-María, el activismo y la pasividad: ${ }^{27}$

«Le ayudaba mucho tener en crédito al confesor, pues con solo una palabra suya quedaba muy satisfecha; y de esta manera el confesor no tenía por qué quebrarse la cabeza, ni ella por qué detenerse en el confesionario y quitar el tiempo y lugar a la otra hermana, porque como ella con algunas comulgaba cada día, quisiera ella que todo el convento comulgara sin acordarse que el Oficio de Marta también es muy necesario en la Iglesia de Dios y también en las Religiones y así el mucho crédito y sujeción que tenía el confesor la ayudaba mucho a vencer esta tentación de escrúpulos demasiados, el llevar siempre en su corazón algo de la Santa y divina Escritura»

${ }^{24}$ AMA. Rocabertí, J. T. de (ed.). 1679. La Venerable...: 9 y 145

${ }^{25}$ Ibídem: 161

${ }^{26}$ Citado por Giordano, L. 2012. «Memoria y tradición en la dominica catalana Hipólita de Jesús» en R. Ma. Alabrús (coord): La memoria escrita de los dominicos: 181 y 184. Sant Cugat: Editorial Arpegio.

${ }^{27}$ AMA. Rocabertí, J. T. de (ed.). 1679. La Venerable...:147. También las dos mujeres Marta y María habían sido citadas por Teresa de Jesús.

Hispania Sacra, LXVII

135, enero-junio 2015, 219-245, ISSN: 0018-215X, doi: 10.3989/hs.2015.006 
Ella defiende una contemplación que no ignore la vida activa de Marta:28

«Otro trabajo hallo yo en la contemplación y es no solo cuando el Prelado me mortifica sacándome de la celda, pero ay, ay dolor cuando el mismo amado, por sí mismo o por sus Ángeles me dicen que me levante de la divina contemplación y que vaya y me humille en cumplir con mis necesidades o con las de mis hermanas (...) tu eres caminante y te has de humillar, quieras o no quieras comer sin gana, beber, vestir, dormir y sufrir fiebre que tienes y todos los disgustos de este destierro, obedeciendo a tus mayores hasta la muerte y sufrir todo cuando viniere de tu amado Jesús que tanto se humilló y padeció por ti, así pues lo hemos de hacer los que nuestro Señor llama a la divina contemplación que seamos muy hermanos de Marta que es la vida activa».

Desde luego, Hipólita no tuvo la capacidad de distanciamiento que refleja Teresa de Jesús respecto a sus propias visiones. La carmelita asumía que podían tratarse de sueños: «Hay personas que se embeben de manera tal en la imaginación que todo lo que piensan claramente les parece que lo ven (...) No están bien despiertas como una persona que ha mucho dormido y soñado y aun no acaba de despertar». ${ }^{29}$

Incluso Teresa aporta explicaciones biológicas a algunas visiones: ${ }^{: 0}$

«Mujeres, que como somos más flacas, ha más lugar para lo que voy a decir, y es que algunas, de la mucha penitencia y oración y vigilias y aun esto son flacas de complexión, en teniendo algún regalo, sujétales el natural, y como sienten contento alguno interior y caimiento en lo exterior y una flaquedad cuando hay un sueño que llaman espiritual que es un poco más de lo que queda dicho, paréceles que es lo uno como lo otro y déjanse embebecer; y mientras más se dejan, se embebecen más, porque se enflaquece más el natural, y en su seso les parece arrobamiento; y llamole yo abobamiento, que no es otra cosa más que estar perdiendo tiempo y salud»

\section{Por otra parte Teresa decía resistirse: ${ }^{31}$}

«Y en tanto extremo, que muy muchas veces querría yo resistir y pongo todas mis fuerzas, en especial algunas que es en público y otras hartas en secreto, temiendo ser engañada. Algunas podía algo con gran quebrantamiento, como quien pelea con un jayán fuerte, quedaba después cansada; otras, era imposible, sino que me llevaba el alma y aún casi ordinario la cabeza tras ella, sin poderla tener y algunas todo el cuerpo hasta levantarte»

\footnotetext{
${ }^{28}$ BUB. Rocabertí, J. T. de (ed.). 1679. La Venerable ...: 203-204

${ }^{29}$ 1951. Obras completas de Teresa de Jesús I, Vida: 712-713. Cap. 20, 19-20. Madrid

${ }^{30}$ Ibídem: 742-743. cap. 25, 6

${ }^{31}$ Ibídem: 713-714, cap. 20, 3-4
} 
Hipólita no tiene el sentido de la paradoja ni de la ironía que tuvo Teresa. Tiene, desde luego, muy clara la distinción entre el tiempo de la oración mental y de la escritura: ${ }^{2}$

«Mas ha de treinta y cuatro años que tengo Oración mental y por la divina Gracia no me he vuelto loca, ni tengo la cabeza enferma, sino muy fuerte (gloria a Dios), ni estoy melancólica, aunque lo soy naturalmente; porque los consuelos que hallo en la Oración mental, me quita toda melancolía y enojo. Porque en mi humilde y bajita oración, no me fatigo la cabeza en hacer lindos discursos de la santa y Divina Escritura (...) y eso lo dejo yo para cuando quiero escribir»

La descripción que Hipólita hace de sus revelaciones y el proceso de unión mística con Dios tiene enorme parecido con las que hace Teresa de Jesús. Al lado de la oración y la mortificación, Hipólita, desde luego, siempre tuvo en la Biblia su principal punto de apoyo, con una cultura escrituraria excepcional: ${ }^{33}$

«A los libros sagrados tenía suma reverencia, a imitación de su padre Santo Domingo, que veneraba y reverenciaba mucho a la Sagrada Biblia. Siempre antes de leer en la Santa y divina escritura se arrodillaba y con gemidos entrañables rogaba a su esposo Jesús le diese su espíritu que le hallase y que nunca lo perdiese. Lo mismo hacía en cualquier libro santo que leyese: o cuando quería escribir también se encomendaba a nuestro Señor Jesucristo rogándole quisiese dictar y guiar todo lo que ella escribiese.»

La Biblia es la cantera de la que extrae ejemplos edificantes de todo tipo, sobre todo de mujeres: Judith, Ana, Esther, Sara...Especialmente sensible era hacia las epístolas de San Pablo: ${ }^{34}$

«También la Sagrada Escritura la hacia llorar, temer y temblar de la palabra de Dios que como se conocía por tan grande pecadora, le parecía que verdaderamente amenazaba a su cabeza y que se decía por ella, más que por alguna otra persona. En particular las Epístolas de San Pablo (ella creía que iban dirigidas a ella) le causaban mil efectos vivos, ahora de temor, ahora de amor, de humillarse, de confianza, de encendidos deseos de Cristo y sobre todo en darle altos conocimientos y sentimientos de Jesucristo»

Hipólita fue exaltada por el canónigo ilustrado Joaquín Lorenzo Villanueva como la única mujer empeñada en difundir la Biblia en lengua vulgar. ${ }^{35}$ Dejando aparte que el juicio de J. Lorenzo Villanueva fue tortuoso por sus giros

${ }^{32}$ Citado por Giordano, L. 2011. «La Contrarreforma y sus críticos...»: p. 43

${ }^{33}$ AMA. Rocabertí, J. T. de (ed.). 1679. La Venerable...: 148, 222 y 223

${ }^{34}$ BUB. Rocabertí, J. T. de (ed.). 1679. La Venerable ...: 46

${ }^{35}$ Lorenzo Villanueva, J. 1791. De la lección de la Sagrada Escritura en lenguas vulgares: LXXXVIII-IX. Madrid. Villanueva fue catedrático de teología en el seminario de Salamanca. Siendo diputado por las Cortes de Cádiz en 1811 escribió obras tan dispares como El jansenismo dedicado al filósofo rancio y Las evangélicas fuentes o El tomista en las Cortes. Vid. 1991. Diccionario biográfico del Trienio liberal, Madrid. 
ideológicos, la realidad es que Hipólita nunca defendió las ediciones en lengua vulgar, como hicieron los protestantes (ediciones de Casiodoro de Reina, Cipriano de Valera, Antonio del Corro, Pérez de Pineda...) y nunca cuestionó la legitimidad de la Vulgata como el texto canónico de la Biblia. Lo que hizo fue, a lo largo de su obra, difundir pasajes de la Biblia en los que mezclaba el latín y el castellano. Nunca teorizó sobre si había que leerla en latín o en lengua vulgar; simplemente partía del supuesto de que había que comentar y aprender de las Sagradas Escrituras porque Hipólita se sentía anclada en la Babilonia de los judíos, un mundo de «sauces infructuosos y amargos» llenos de confusión que necesita la iluminación ejemplar de la Biblia. ${ }^{36}$

Aunque Hipólita jamás tuvo problemas con la Inquisición en vida, ciertamente vivió una época en la que la espiritualidad generaba no pocas inquietudes. Hay que tener presente que hasta fray Luis de Granada había sido puesto bajo sospecha por Melchor Cano, bajo la sombra del proceso de Carranza: ${ }^{37}$

«A Fray Luis de Granada le podría la Iglesia reprehender gravemente en tres cosas: la una en que pretendió hazer contemplativos e perfectos a todos e enseñar al pueblo lo que a pocos dél conviene, porque muy pocos populares pretenderan yr a la perfección por aquel camino de Fray Luis, que no se desbarata en los exercicios de la vida activa competentes a sus estados, e por el provecho de algunos pocos da por escripto doctrina en que muchos peligraran por no tener fuerza ni capacidad para ello».

El racionalismo preventivo parece desatarse en el ámbito eclesiástico desde fines del siglo XVI. El arcediano Juan de Horozco, en 1588, con su Tratado de la verdadera y falsa profecía y el benedictino Fray Leandro de Granada, con su Luz de las maravillas en 1607, habían intentado fijar las fronteras de la realidad y el imaginario. Especialmente surgieron los recelos respecto al imaginario femenino que pone en evidencia Fray Juan de los Ángeles en sus Diálogos de las conquistas del reino de Dios (1595). ${ }^{38}$

Y están como testimonio los múltiples procesos a monjas y mujeres ilusas o iludentes que se desatan ya desde mediados del siglo Xvi. Ejemplos son la presunta endemoniada Magdalena de la Cruz, abadesa franciscana, que después de gozar excelentes relaciones con el Inquisidor Manrique acabó procesada por la Inquisición en 1546; María de Meneses, la monja de Lisboa o monja de las llagas, muy bien valorada por Fray Luis de Granada, fue procesada en 1588 y Luisa de la Ascensión, la monja de Carrión, agustina, que, a pesar de sus buenos contactos con la cúpula cortesana, fue procesada en 1635. ¿Y qué decir

\footnotetext{
${ }^{36}$ Citado por Giordano, L. 2001. «La Contrarreforma y sus críticos...»: 32

${ }^{37}$ Citado por Caro Baroja, J. 1978. Las formas complejas de la vida religiosa: religión, sociedad y caràcter en la España de los siglos XVI y XVII: 35. Madrid: Galaxia Gutenberg.

${ }^{38}$ Ibídem: 41-42
} 
del mundo profético de Lucrecia de León y el tránsito de su excelente consideración a su caída? ${ }^{39}$ Los propios problemas que sufrió Teresa de Jesús con la Inquisición debieron afectar a Hipólita. Es importante recordar las prevenciones manifestadas por el dominico Padre Báñez en la censura de la Vida de Teresa de Jesús, en 1575 , aún con todo el cariño que demuestra tener a la santa: ${ }^{40}$

«Solo una cosa hay en este libro en que poder reparar y con razón basta examinarlo muy bien y es que tiene muchas revelaciones y visiones, las cuales siempre son mucho de temer, especialmente en mujeres, que son más fáciles en creer que son de Dios y en poner en ellas la santidad, como quiera que no consista en ellas, antes se han de tener por trabajos peligrosos, para los que pretenden perfección; porque acostumbra Satanás transformarse en Ángel de luz y engañar las almas curiosas y poco humildes, como en nuestros tiempos se ha visto. Más no por eso hemos de hacer regla general de que todas las revelaciones y visiones son del demonio (...) Esta mujer a la que muestra su relación, aunque se engañase en algo, a lo menos no es engañadora, porque habla tan llanamente, bueno y malo y con tanta gana de acertar, que no dexa dudar de su buena intención y cuanto más razón de que semejantes espíritus sean examinados, por haber visto en nuestros tiempos gente burladora so color de virtud tanto más conviene amparar, a los que con el color parece tienen la verdad de la virtud (...) Considerando yo ser así verdad lo que tengo dicho, siempre he procedido con recato en la examinación de esta relación vivida de esta religiosa y ninguno ha sido más incrédulo que yo en lo que toca a sus visiones y revelaciones, aunque no en lo que toca en la virtud y buenos deseos suyos (...) Y tampoco menosprecio sus revelaciones y visiones y arrobamientos, antes sospecho que podían ser de Dios como en otros santos lo fueron. Más en este caso siempre más seguro quedar con miedo y recato, porque en habiendo seguridad tiene lugar el diablo de hacer sus tiros y lo que antes era quizá de Dios se trocará y será del demonio».

La autobiografía de la Venerable, responde a la situación de tensión que sufrió. En su memoria debió pesar la experiencia vivida por la generación anterior (aquellos autos de fe de 1559, con el proceso a Carranza) con la estela de hipersensibilidad ante la herejía que aquella situación había generado, a lo que se añadió el escepticismo creciente a las visiones. La escritura, respaldada por sus confesores fue la alternativa mejor que Hipólita encontró a sus propios miedos, a los herejes y a los perseguidores de las herejías. Hipólita estuvo marcada por la obsesión, por el rumor y la opinión y en el esfuerzo de garantizar su ortodoxia, ante los peligros que la rodeaban, recurrió a la disimulación y al silencio como autoprotección: ${ }^{41}$

${ }^{39}$ Ibídem: 40; Imirizaldu, J. 1977. Monjas y beatas embaucadoras, Madrid: Editora Nacional; Kagan, R. 1991. Los sueños de Lucrecia. Delitos y profecías en la España del siglo XVI, Madrid: Editorial Nerea; Sánchez Lora, J. 1988. Mujeres, conventos y formas de religiosidad barroca. Madrid: Fundación Universitaria Española.

40 1951. Obras completas de Teresa de Jesús, I, Vida: 880-881. Madrid.

${ }^{41}$ AMA (Archivo del Monasterio de los Ángeles, Sant Cugat). Signatura: 1/01/19, Libro 1 del manuscrito: La vida de sor Hipólita de Rocabertí. Mercedes que Dios le hizo: cap. 55

Hispania Sacra, LXVII

135, enero-junio 2015, 219-245, ISSN: 0018-215X, doi: 10.3989/hs.2015.006 
«Cuando alguna religiosa venía a su celda disimulaba y si era necesario, para consolar a la hermana, ella tenía paciencia pero si no era necesario ella hacía tal rostro, sin ningún disimulo para evitar hablar y le decía: lo siento, quiero estar sola en mi casa, por amor de Dios. ¿Por qué tengo que hablar yo con las criaturas donde hay tantos peligros? Pues solo me gusta meditar y tratar con mi santo esposo Jesús que siempre me es dulce y sabroso y con sus santos de la gloria pues tratando con ellos no hallo peligros, ni me tengo que arrepentir de las palabras dichas y que sigo a Jesucristo en este insigne Evangelio (...) Todo esto es peligroso porque ello se puede tergiversar en el habla e incluso se puede sufrir engaño y el demonio puede incitar a muchas almas y a grandes errores».

En definitiva, la religiosidad de Hipólita es expuesta en su autobiografía de modo muy similar a la de la Vida de Teresa, con parecidos buscados equilibrios entre visiones y meditaciones, entre gracia y voluntad. Indudablemente Teresa de Jesús sería su referente. Se distingue de la carmelita por su perfil más solitario y encerrado en si misma (no tuvo la vocación inquieta y andariega de la Teresa fundadora), su antijudaísmo y su lenguaje menos llano que el de Teresa.

\section{LA CONSTRUCCIÓN DE LA IMAGEN DE HipÓLITA}

La primera glosa de Hipólita la hizo su confesor jesuita Jaume Puig, tras la muerte de ésta. Puig buscó ante todo la comparación con Teresa de Jesús, que había sido canonizada dos años antes. La transverberación la compara el confesor con las apariciones de Jesucristo a Hipólita: ${ }^{42}$

«Sobre su cabeza y frente quiso llevar siempre Hipólita el velo consagrado con las espinas de Cristo, para que le fuesen un continuo despertador, como decía ella de su sagrada Pasión. Similem illam fecit in gloria sanctarum. A la virgen Santa Teresa de Jesús, envió Cristo varias veces un Serafín, con un dardo de oro, y en la punta del hierro una lengua de fuego, y quedaba toda encendida en el amor de Dios cuando con el atravesaba su corazón. A Hipólita, entre otras, una vez le apareció Cristo, y le dijo lo que antes había dicho en su Evangelio: Ignem veni mittere in terram y diciendo y haciendo la metió en la fragua del amor divino, que es el costado de Cristo y quedó toda encendida y abrasada de amor».

El jesuita identifica el camino de perfección teresiano con sus tres vías, con la misma metodología mística de Hipólita (oración, mortificación y penitencia, asesoría permanente del confesor, acoso del demonio, arrobamiento como merced divina, prodigios maravillosos y visitas de Jesucristo, de santos y de maestros edificantes) acercando el mundo espiritual de las dos mujeres.

${ }^{42}$ 1624. Sermón que predicó el padre Jaime Puig rector de la Compañía de Jesús a las honras que hizo el monasterio de nuestra señora de los Ángeles a la Venerable sor Hipólita de Rocabertí y Soler: 11. Barcelona. 
Puig aporta algunas precisiones que en la autobiografía no se habían hecho (los cinco años de silencio absoluto; las enfermedades que también duraron cinco años; las apariciones que se produjeron de los 26 a los 73 años) y subraya la paradoja de que escribiera tantas obras (precisa el número: 21 libros, 6 de su vida) desde sus limitaciones, con un punto de misoginia: «Que es cosa maravillosa y milagrosa que una mujer siempre enferma, haya ordenado, hecho y escrito tantas y tan varias cosas». Reitera las virtudes de capacidad de silencio, pureza y candidez, humildad, castidad (comparándola con Catalina de Siena), obediencia y pobreza.

Es interesante también el esfuerzo por hacer ver que sus libros son útiles para todos. Los eclesiásticos aprenderán la devoción con que se han de rezar las horas canónicas. Las religiosas sabrán de los peligros de los locutorios. Y los seculares la reverencia con que se ha de asistir a los templos.

Por último, Puig se esfuerza por vincular a Hipólita a la Compañía de Jesús. Le atribuye, que, conjuntamente, con otras tres religiosas del Convento, un padre jesuita les dio los «Ejercicios Espirituales de nuestro santo padre Ignacio». Soslaya la descripción de toda la vertiente contemplativa, para solo referirse a la oración mental, el silencio y las penitencias como los fundamentos de la religiosidad de Hipólita. Lanza un recordatorio de que» son las obras satisfactorias y que cuando las fuerzas y la salud no daban lugar bastaban la voluntad eficaz de hacerlas». En la polémica, dominicos-jesuitas sobre la gracia y el valor de las obras, Puig deja claramente en evidencia su posición llevando a Hipólita a su terreno.

Al principio de su glosa, Puig llega a plantear: ${ }^{43}$ «Con esto no pretendemos, como no podemos beatificarla ni canonizarla, sino que Dios sea glorificado, honrada la virtud y yo pagar en algo la confianza que esta sierva de Dios hizo de mi en vida»

El empeño del padre Puig en capitalizar la figura de Hipólita para la Compañía no tuvo continuidad. La confrontación de dominicos y jesuitas se radicalizó en la década de 1620 y 1630, y la separación de Cataluña de la monarquía española en el período 1641-1652, contribuyeron decisivamente a que Hipólita quedara en un momentáneo limbo. La elección de Fray Tomás de Rocabertí, sobrino de Hipólita, como maestro general de la orden de los dominicos relanzó el interés por Hipólita. En 1643-47, las monjas de su monasterio hicieron en Barcelona una edición recopilatoria de algunos de sus tratados espirituales. En 1660, Juan Tomás haría una nueva edición añadiendo algunas de sus obras espirituales. Pretendía exaltar a su propia familia (lo había hecho ya Hipólita en las glosas de sus primas) y, desde luego, a la orden de Predicadores. En 1669, el propio

\footnotetext{
${ }^{43}$ Ibídem: 4
} 
Juan Tomás de Rocabertí publicó en Barcelona su tratado Theologia mística, obra que se caracteriza por un tono didáctico y formador para los futuros directores espirituales. En la misma, Juan Tomás se manifiesta ecléctico. Plantea dos tipos de oración mental, intelectiva y afectiva. La primera es la común, larga y trabajosa. La segunda es secreta y conocida por pocos. Para él hay cuatro fases en el encuentro místico: discusión, recogimiento activo, recogimiento infuso sobrenatural y quietud. De la actividad a la pasividad. Al mismo tiempo que parece defender la cultura del trabajo para subir al monte de la perfección cristiana (el valor de la voluntad) glosa la calidad extraordinaria de los pocos privilegiados que tienen acceso directo a la contemplación infusa. El equilibrio disciplina-gracia, debe estar en todo momento presente. Contemplación infusa o sobrenatural, sí, pero no todos pueden aspirar a lo mismo. El pesimismo de la inteligencia lo neutraliza Rocabertí con el optimismo de la voluntad. Su imagen de Hipólita es el de una espiritual pero menos encerrada en sí misma, no tan aislada ni silenciosa. Así desterraba los riesgos de que a la figura de su tía se la tiñera del temido iluminismo. ${ }^{44}$

El debate místico estaba entonces en plena efervescencia. En 1662, el dominico Tomás de Vallgornera había adaptado la mística teresiana a los filtros de Santo Tomás de Aquino. Había promovido el polémico concepto de contemplación adquirida, teorizada por primera vez por el carmelita P. Tomás de Jesús (1620), reivindicando la trascendencia del conocimiento y distinguiendo los perfectos que poseen la verdadera sabiduría, de los imperfectos que se quedan en la vía purgativa. ${ }^{45}$

La jerarquía entre los receptores de la gracia parecía fijarse. Se había de pasar impositivamente por cada vía. Es la vida activa la que dispone a la contemplativa. San Agustín quedaba más marginado. El recogimiento místico exigía matices y condiciones. La libertad de la unión espiritual de Hipólita con Dios quedaba más controlada. El fantasma del viejo iluminismo agobiaba y había que depurar el punto de vista dominicano de toda sospecha. Las prevenciones de Báñez respecto a santa Teresa parecían más vigentes que nunca.

\footnotetext{
${ }^{44}$ Rocabertí, J. T. de. 1669. Theología mística, primer tomo. Instrucción del alma en la oración y meditación, Barcelona; Garganta, J. Ma. O.P. 1981. «Un capítol gironí d’Història espiritual» en Annals de l'Institut d'Estudis Gironins 25,2: 133-144

${ }^{45}$ Vallgornera, T. de. 1662. Mystica Theologia D. Thomae, Utriusque theologiae scolasticae et misticae principis. Barcelona; Vid. Andrés, M. 1994. Historia de la mística de la Edad de Oro, en España y América: 384-385, Madrid, BAC; González-Arintero, J. OP. 1980. La verdadera mística tradicional: 238- 275 y 428-430. Salamanca: Editorial Fides, $2^{\text {a }}$ Ed. Niega que exista otra contemplación verdadera que la infusa, a la cual está llamada la totalidad de los fieles; Bernard, Ch. A. 2006. Teología mística: 158-169. Burgos: Monte Carmelo; Garrigou-Lagrange, R. OP. 1944. Las tres edades de la vida interior: 545-1135. Buenos Aires: Ed. Desclée, de Brower; Vilanova, E. 1986. Història de la teología cristiana, vol II. Pre-reforma, reformes, contrarreforma: 484-491. Barcelona: Facultat de Teología de Cataluña-Editorial Herder.
} 
Los dominicos después del desgaste sufrido por la polémica De auxiliis no parecían estar dispuestos a embarcarse en aventuras místicas. Sin embargo, Juan Tomás de Rocabertí lanzó su propio órdago en enero de 1671, con la promoción del proceso de beatificación de su tía Hipólita. Había caído el jesuita J. E. Nithard, valido de la reina Mariana de Austria e Inquisidor General en 1669. Los dominicos habían trabajado mucho para conseguir su caída política. Habían escrito múltiples papeles contra él como los de Fray Clemente Álvarez, dominico del convento de San Pablo de Valladolid; el Provincial Juan Martínez y otros en el marco del debate sobre el inmaculadismo, fustigando el bloqueo impuesto por los jesuitas para que el rey tuviera un confesor dominico como Fray Pedro Álvarez de Montenegro. En las entretelas del poder se movía Don Juan José de Austria con el que siempre colaboró Juan Tomás de Rocabertí. Ciertamente Nithard tuvo que salir de la corte, pero fue nombrado embajador extraordinario y cardenal por parte del papa Clemente X. Desde Roma sería un freno permanente para los intereses dominicanos hasta su muerte en $1681 .^{46}$

1671 parecía el momento propicio para la estrategia de Juan Tomás de Rocabertí de promover a Hipólita como referente de la teología dominicana de ese momento que unía razón y sentimiento, voluntad y gracia divina, actividad y pasividad. De hecho, ese año, Clemente $X$ canonizaría a tres españoles: el rey medieval Fernando III el Santo, el jesuita Francisco de Borja y los dominicos Luis Beltrán y Rosa de Lima. Borja y Beltrán eran de la generación de Teresa de Jesús. Rosa de Lima de la misma generación que Hipólita. Pero la religiosidad de Hipólita presentaba problemas entonces difíciles de asumir.

La causa de beatificación de ésta se inicia, efectivamente, en enero de 1671. Empieza con la declaración de la priora, Angélica Masmitia, del convento de los Ángeles, que la había conocido siendo ella novicia. Ésta testificó a su favor, confirmando su reputación. Reconoció que fue docta, servil, respetuosa y caritativa. También lo hicieron la subpriora, Teresa Prexano; su amiga y confidente, Emerenciana Rossell, y las otras religiosas del convento: María Magdalena Moix, María Caminet, Plácida Gualbes, Jerónima Guardiola, Raimunda Rius, María Gracia Palau y Astasia Colomer que la sobrevivieron.

Las monjas subrayan detalles precisos sobre su pobreza (zapatos rotos en los que veían los dedos de los pies), ayunos (incluso en plena calentura), sacrificios (cilicios de hierro y de esparto), retiro y soledad (vivía en una cueva dentro de la clausura del convento, junto al coro, desde donde se veía el altar mayor y el presbiterio, había incluso solicitado el emparedamiento), comunión diaria,

\footnotetext{
${ }^{46}$ Pilo, R. 2010. Juan Everardo Nithard y sus causas no causas. Razones y pretextos para el fin de un valimiento: 245-257. Madrid: Sílex; Callado, E. 2011. Sin pecado concebida. Valencia y la Inmaculada en el siglo XVII. Valencia: Institució Alfons el Magnànim; Callado, E. 2007. Por Dios y por el rey. El Inquisidor Fray Juan Tomás de Rocabertí. Valencia: Institució Alfons el Magnànim.
} 
control en el hablar (protegía su castidad evitando hablar con hombres, nunca miraba a los ojos de los varones, y sus confesores no pasaban de un credo), disciplina para dormir (dormía en un lecho que no tenía cuatro palmos de ancho) sobre un pilón de madera por colchón.

Las mismas monjas reconocen que ejerció un excelente magisterio de novicias, que su oración mental siempre fue regulada por sus confesores y que obtuvo el apoyo favorable de los doctores y teólogos de Barcelona. Además corroboran que no solo fue una buena escritora sino una buena predicadora dentro del convento y en toda la ciudad de Barcelona, enseñando sus libros y escritos sobre la caridad, la justicia con el debido cumplimiento de todas las observancias y constituciones de la orden y plena ortodoxia respecto a la iglesia Romana y al Papa y obediencia máxima a las instituciones eclesiásticas.

En la misma línea de las declaraciones de las monjas se aportaron los testimonios del confesor Broquetes, el padre Jacobo de San Genís, el doctor Llorens y la señora Ana Ferrer, mujer de una autoridad de la Audiencia. El obispo de Solsona, el benedictino Luis de Pons i de Esquerrer, escribió al arzobispo de Barcelona, el mercedario Ildefonso Sotomayor, manifestándose partidario de la beatificación de Hipólita. Más discretos en su valoración de Hipólita fueron los obispos de Gerona (Francesc Dou) y Tarragona (el también benedictino Juan Emanuel y de Espinosa). El arzobispo de Barcelona no se manifestó tampoco especialmente partidario de la misma. Los asuntos que suscitaron mayor complicación fueron los de sus milagros y el caso de la novicia Francesca Boria Gualba.

El milagro más debatido fue el del niño Salvador Petit i Marés, de 9 años. Varios testigos afirman que a este niño enfermo los médicos daban por muerto, por lo que lo llevaron a la venerable Hipólita para que lo curase. La Rocabertí pasó toda la noche rezando por él. Gracias a las prácticas oratorias de ella el niño sanó. Lo testificaron Miguel Comas, el prelado y beneficiado de la Iglesia de Santa María del Mar de Barcelona, catedrático de Teología en la Universidad de Barcelona, los nobles Anton y Gertrudis de Camporrells y el tío del niño, el médico Francisco Marés, beneficiado de la Iglesia del Arcángel San Miguel.

Pero la cuestión más polémica del proceso de beatificación fue el asunto de la enfermedad de Francisca Boria, doncella de veintiún años, hija de Bernat Boria, doctor en medicina i María de Gualba. Esta mujer no quería comer, tenía fiebres continuas y vomitaba todo lo que comía. Los padres pidieron la intervención de la Venerable que había muerto hacía cuarenta y siete años, el 21 de diciembre de 1671. El médico que la trataba era el doctor Jacint Andreu «no podia retenir lo aliment $\mathrm{i}$ després tenia gran mucositat i fluix al pit i escupia sang». Cuando se invocó a Hipólita la enferma vomitó un «vòmit tant extraordinari que entre d'altres matèries tragué tres porcions que eren de una sustància 
blanca quasi membranosa i forta i en figura de un calamar de la llargària del dit petit de la mà i quedà després aliviada». El 30 de enero entre las nueve $\mathrm{y}$ diez de la noche, sintiéndose con fiebre y angustiada, los padres invocaron de nuevo a Hipólita para que salvara a su hija e incluso la vistieron con dos prendas suyas (una camisa y una mantilla) y le enseñaron una estampa de aquella, frente a la cual, la enferma mostró animadversión. Los padres reclamaron la ayuda del doctor Fontanet, jesuita, que había sido lector de Filosofía en Cordelles, de Teología en Lérida y después catedrático de Cordelles. Este leyó en voz alta los prodigios que había hecho Hipólita y la enferma reaccionó negativamente. Le leyeron libros de la Venerable, como el Tratado de los Ejercicios Espirituales y le expusieron imágenes de la religiosa. La enferma no solo no se curaba sino que se agravaba su estado. Los demonios parecían aliados de Hipólita. Intervino también como exorcista el franciscano Pedro Benet. Finalmente, se llamó al jesuita Teodoro Maurins. La enferma se quedó inmóvil, quieta y paralizada, al enseñarle una cajita de huesos de la Venerable. Los jesuitas consideraron que la tal Francisca Boria estaba poseída por el diablo y que la invocación a Hipólita no la favorecía. Finalmente, el demonio se fue del cuerpo de Francisca cuando ésta instada por los jesuitas profesó votos y la hicieron vestir el hábito de beata de la Compañía de Jesús el 19 de julio de $1672 .{ }^{47}$ La memoria del caso de las endemoniadas monjas de San Plácido iniciado en 1628 y saldado en 1633 con la condena del confesor, el benedictino García Calderón y la priora Teresa Valle de la Cerda debió pesar en el ambiente.

Aunque en ese mismo año se publicó en Roma, en italiano, una síntesis de la vida de Hipólita de Jesús, que reiteraba las virtudes reflejadas en la autobiografía, editada en $1669,{ }^{48}$ el proceso se estancó, momentáneamente, en 1673, y continuaría entre 1674-76. El juez instructor que interrogó a los testigos fue precisamente el antes citado, el dominico Tomás de Vallgornera. Se recogieron nuevos testimonios del franciscano Pablo Soler, primo de Hipólita, el padre Comes, y otras personas y se incidió en las visiones de Hipólita. Las monjas Petronila Ardèvol y Verónica Aymerich declararon haber visto como el día de la Asunción se le había aparecido a Hipólita la virgen María. También se declara que cuando le dio la comunión el obispo Llorens salió de su boca una esfera resplandeciente como un fuego. La monja Ana Maria Vera, la vio abrazada y de pie a una imagen de Cristo petrificada en su celda. Se reiteró asimismo la imagen del perfume que emanaba del cadáver de Hipólita y que certificaron

\footnotetext{
${ }^{47}$ AMA (Archivo del Monasterio de los Ángeles, Sant Cugat). Signatura: 01/18D. Proceso diocesano en la causa de beatificación a Hipólita de Jesús.

${ }^{48} 1672$. Breve ristretto della vita maravigliosa e delle virtú mirabili della venerabile madre e serva di Dio Suor Ippolita di Giesu, nel secolo chiamta D. Isabella de Roccaberti, monaca dell'ordine di S. Domenico nel religiosissimo monastero degl' Angeli della città di Barcellona/composto da un religioso del medesimo ordine. Roma.
} 
las enfermeras religiosas que la atendieron, Agnese y Dionisia Ninot, así como que un año después de su muerte, el cuerpo de Hipólita seguía incorruptible. La monja Lucrecia Toco quiso conservar un dedo del pie de la Venerable y al no consentirlo la priora consiguió cortar un pedazo de uña del pie del que supuestamente brotaron gotas de sangre viva. La imagen de la muerte de Hipólita mimetizaba la que había transmitido el biógrafo de Santa Teresa de Jesús, Francisco de Ribera en 1590 , tras la muerte de la carmelita. ${ }^{49}$

Llama la atención la cantidad de preguntas que se hicieron en el proceso de Roma en torno a las huellas públicas de la memoria de Hipólita. Se preguntó sobre el sepulcro donde estaba enterrada, en qué capillas o lugares había imagen de ella, si existían inscripciones o epitafios, si se conocía lugares de culto, si se habían puesto lámparas o candelas luminarias en su sepulcro y si su imagen había sido esculpida o pintada.

La conclusión emanada de las respuestas es que ese culto público, a la memoria de Hipólita, era limitado. No tenía una sepultura especial. El sepulcro no tenía inscripciones, ni coronas, ni ornamentos. Eso sí, los testimonios subrayan que incluso un año después de muerta el culto a la dominica de la ciudad de Barcelona no había disminuido y todos reconocían su fama en Barcelona y en Cataluña. En la causa de beatificación se reiteró la imagen de las mortificaciones de Hipólita, subrayando su capacidad de pronosticar el futuro y precisando que recibía visitas de la nobleza y que tenía gran capacidad de convicción y persuasión sobre las prioras. Ciertamente el papel de los jesuitas fue decisivo al involucrar la memoria de Hipólita en el caso de la presuntamente endemoniada, la novicia Francisca Boria. ${ }^{50}$

El barco de la causa de beatificación volvió a encallarse. En 1675 publicaba Miguel de Molinos su célebre Guía espiritual, la obra clave del quietismo, con la sublimación de la vida contemplativa y la abolición de la voluntad.

Molinos seria procesado por la Inquisición en 1685, condenado a reclusión perpetua y prohibida su obra por Inocencio XI. El libro llevaba en su edición romana original, cinco legitimaciones del trinitario Ibáñez de Villanueva, el carmelita descalzo Domingo de la Santísima Trinidad, el capuchino Francisco Xerés, el jesuita Martín de Esparza y el trinitario Fray Diego de Jesús. Ningún dominico. ${ }^{51}$

\footnotetext{
${ }^{49}$ AGOP (Archivo General de la Orden de Predicadores. Santa Sabina, Roma). Signatura: X.1377/c. 1671. Declarantes en el proceso de beatificación de Hipólita de Roma; Signatura: X.1377a. 1676. Congregatione Sacrorum Rituum sive Eminentissimo, ac Reverendissimo card. Portocarrero, Roma.

${ }^{50}$ AGOP. Signatura: X. 1377b. 1671. Proceso de beatificación de Hipólita de Jesús: 30

${ }^{51}$ Caro Baroja, J. 1978. Las formas complejas de la vida religiosa .... 482.
} 
La sombra del quietismo como presunta herejía a perseguir, con Hipólita de sospechosa avanzadilla y la alianza de los demonios con la dominica en el cuerpo de una pobre enferma fueron argumentos suficientes para frenar el proceso de beatificación. La auténtica religiosidad de Hipólita se distorsionó radicalmente porque fueron muchas las nuevas variables en juego, desde el descrédito de todo lo que tenía que ver con manifestaciones iluministas, diagnosticadas en clave del perseguido quietismo al sordo enfrentamiento entre dominicos y jesuitas radicalizado en estos años.

Debieron contar mucho las palabras del padre Alonso de Mier, procurador de la orden de San Benito, encargado de la revisión y aprobación de la autobiografía ya en agosto de 1671 que daría el visto bueno a la edición diciendo: ${ }^{52}$

«En relación a la Doctrina no he encontrado nada que se oponga a la pureza católica o buenas costumbres, antes bien todo lo contenido en este escrito, respira un celo Apostólico, explicado con pías palabras y con singular literatura y erudición, obra por todas partes admirable y que lo será en los siglos venideros (...). ¿Quién no ha de admirar en la pluma de una mujer? Principalmente si atiende que para la inteligencia de la lengua latina y sagrada escritura no tuvo otros maestros que sus ojos (...)».

Pero manifestaba algunos recelos, los viejos recelos, respecto a las revelaciones descritas por la monja en su biografía:

«En cuanto a las revelaciones y lo que a ellas conduce, puedo decir asimismo no he hallado cosa alguna repugnante a la verdadera doctrina de la Iglesia. Ahora, en el punto de si estas son verdaderas? Dios lo sabe. Materia es muy dificultosa, aun a los de mayor experiencia en discernir espíritus, distinguir las verdaderas de las falsas por los peligros a que todas las revelaciones particulares están sujetas. Algún escrúpulo podía considerarse en estas que la Venerable Hipólita dice le acaecieron así por su frecuente multitud, como porque algunas de ellas son de cosas que raras ocasiones se revelan y manifiestan (...) Sola la frecuencia de las revelaciones las hace sospechosas, principalmente si son de materias extrañas que se manifiestan pocas veces y que no conviene saberse, como la certeza de la salvación, confirmación en gracia (...) Añádese a esto el padecer de la Venerable Hipólita los accidentes de melancolía, vehemencia de aprehensión, frecuente dolor y debilidad de cabeza y continua calentura, en la conformidad que ella misma lo refiere en varias partes de sus libros»

Acababa concluyendo que con las revelaciones de Hipólita:

«Pesan como con fiel balanza sus virtudes, verdad y heroicidad de ellas de cuyos términos pende el juicio de las revelaciones, se puede permitir su lectura, observándose el decreto de Urbano VIII sobre la publicación y seguridad que se les ha de dar. Este es mi sentir y el que refiero a la Sacra Congregación, que no he hallado cosa en toda

${ }^{52}$ BUB. Rocabertí, J. T. de. (ed.). 1679. La Venerable.... Introducción. El texto de Mier está escrito en Roma en la Hospedería de los Españoles el 20 de agosto de 1671.

Hispania Sacra, LXVII

135, enero-junio 2015, 219-245, ISSN: 0018-215X, doi: 10.3989/hs.2015.006 
esta obra que pueda impedir ni puede suspender el curso de la causa de Beatificación y Canonización y se pueda proceder con toda seguridad al progreso y despacho de ella».

Pese al dictamen final, el recelo de Mier flotó a lo largo de todo el proceso de beatificación. La reacción de Juan Tomás de Rocabertí fue rotunda: el salto hacia delante. En 1679 se publicaba finalmente la autobiografía convenientemente adaptada al mismo tiempo que el cronista Antonio de Lorea escribía una biografía de Hipólita que recogía alguno de los temas aportados por el proceso de beatificación, también hábilmente reconducidos. Al mismo tiempo, Juan Tomás, entre 1679 y 1685, promovió una edición de las obras completas de Hipólita que empezó con la publicación De los Sagrados huesos de Cristo y acabó con el libro Reconocimiento de los amigos del cielo.

La biografía de Hipólita escrita por Antonio de Lorea intentó ser un refuerzo para incentivar la imagen gloriosa de la misma. Lorea era navarro, estudió en la universidad de Almagro y se ordenó en 1657. Ganó fama de gran predicador recorriendo sobre todo Andalucía. Escribió una crónica histórica de los dominicos en Andalucía y muchas vidas de santos, género del que fue un verdadero maestro. Escribió las vidas de Santa Rosa de Lima (1671), Pío V (1673), Fray Pedro de Tapia, arzobispo de Sevilla (1676), Toribio Alfonso Mogrovejo, arzobispo de Lima, el propio fray Juan Tomás de Rocabertí (1679) e Hipólita (1679).

Escribir la biografía del propio Juan Tomás en plena vida no debió ser fácil y supuso alguna colisión con el arzobispo. Tampoco la de su sobrina. Describió de manera muy naturalista las mortificaciones: ${ }^{53}$

«Las disciplinas con que afligía su cuerpo eran de dos maneras, unas de cordeles, ordinarias: otras eran cadenas de hierro, puesto en medio de cada ramo un garfio y otro a la punta y como si el golpe no fuera bastante para atormentar las carnes, con los garfios tirando desgarraba cuanto las cadenas habían atormentado (...) Por todas partes estaba rodeado de cilicios. Rodeaba la cintura con cadenas, que guarnecidas a puntas, cada una era un puñal a sus carnes. Otras veces se ponía un tejido de juncos marinos que clavándose en el cuerpo las espinas, no había parte de él, que no estuviese con heridas y corriendo sangre sujetose tanto a estos rigores que continuamente trajo puesto el cilicio»

Contó con detalle los milagros que efectuó la Venerable sobre varias religiosas, curando de sus enfermedades a Juana de Astor, Magdalena Esteve y Feliciana Verdaguer y se detuvo explicando que cuando se abrió el sepulcro de Hipólita un año después de su muerte «la hallaron de la misma forma que había dicho, cumpliéndose su profecía puntualmente porque parecía que el cuerpo no

${ }^{53}$ Lorea, A. de. 1679. La Venerable Hipólita de Jesús de Rocabertí. Sacado de los procesos de beatificación y canonización y otros instrumentos auténticos: 12-13 y 208. Valencia: Imprenta Vicente Cabrera. 
solo estaba cubierto de ceniza sino todo él que parecía ser una estatua formada de masa de ceniza». ${ }^{54}$

Menciona, de pasada, el caso Boria: ${ }^{55}$

«Y en especial en una ocasión que más lo había menester, por andar el demonio más suelto y los hombres sin freno, considerando a aquella madre que tenía una hija poseída de Satanás, que la atormentaba cruelmente y vino a Jesucristo a pedirle tuviese lástima de ella».

Evidentemente no le debió gustar a Juan Tomás de Rocabertí la mención a la endemoniada. Lo que se refleja en la obra de Lorea es el intento de desprender a la monja de la vertiente más inquietante entonces: su extraordinario mundo interior que la acercaba al temido quietismo y proyectarla hacia fuera de su intimismo tanto en su vertiente docente con las monjas como en su beligerancia con los herejes: ${ }^{56}$

\begin{abstract}
«De esta firmeza en la fe nacía aquel celo de la conversión de las almas y al mismo tiempo que estaba encerrada en su monasterio quisiera estar predicando en las sinagogas de los judíos, para desengañarles de sus errores y reducirlos a la fe y al amor de Jesucristo. Quisiera estar en Inglaterra y Holanda reduciendo a los herejes: en el Japón, China e Indias, trayendo a sus idolatras a lavar sus culpas en las aguas del bautismo. En toda África y Asia, para obligar a los Moros y Turcos dejasen la conciencia de su maldito profeta Mahoma. Continuamente en sus escritos exhorta a los ministros del Evangelio, tengan lástima de tantas almas, como perecen en la Infidelidad y vayan a predicarles, pues el señor los admitió para obreros en su casa (...)».
\end{abstract}

El esfuerzo de Rocabertí y Lorea fue vano. En 1685, la Inquisición dirigida por el gallego Diego Sarmiento de Valladares se lanzaba a incluir en el Índice de libros prohibidos varias obras de Hipólita con el estigma del quietismo a cuestas. Fueron prohibidas su propia autobiografía y, con ella, los libros más próximos al intimismo místico: De los sagrados huesos de Cristo, De los divinos cantares de Salomón, Tratado del rendimiento del tiempo perdido, Tratado de las virtudes y de los santos ángeles. En 1687 entró también en el Índice de libros prohibidos la biografía de Lorea. En medio de la persecución no deja de ser curioso que vuelve a editarse un Epitome de los veinticuatro tomos que escribió la Venerable en 1688 y una Exposición literal mística y moral sobre los lugares más selectos de los cuatro Evangelios en 1694.

Fue el canto de cisne de la memoria de Hipólita. El empeño puesto por Juan Tomás de Rocabertí para la edición de las obras de su tía y su causa de

\footnotetext{
${ }^{54}$ Ibídem: 209

${ }^{55}$ Ibídem: 36

${ }^{56}$ Ibídem: $34-35$
}

Hispania Sacra, LXVII

135, enero-junio 2015, 219-245, ISSN: 0018-215X, doi: 10.3989/hs.2015.006 
beatificación se vio saldado con el fracaso por la presión de los jesuitas en su contra, las dudas y vacilaciones de los propios dominicos y algunos poderes fácticos en Roma hostiles, con el estigma del iluminismo quietista flotando. Nithard pudo encontrar en Hipólita la ocasión del ejercicio de su venganza contra la orden de Predicadores. Juan Tomás recibió una inesperada compensación con su nombramiento como inquisidor general en 1695. Curiosamente, en su ejercicio como inquisidor tuvo que pechar, en los años finales del siglo XVII, con la cuestión del presunto endemoniamiento del rey Carlos II y el debate sobre los hechizos y exorcismos subsiguientes. Los demonios del caso Boria parecían volverse a conjurar contra el destino de los Rocabertí. Juan Tomás murió en junio de 1699, posiblemente envenenado, con su gran sueño frustrado, el de ver elevada a los altares a su querida tía. ${ }^{57}$

\section{FuENTES Y BIBLIOGRAFÍA CITADAS}

AGOP (Archivo General de la Orden de Predicadores. Santa Sabina, Roma). Signatura: X. 1377/c. 1671. Declarantes en el proceso de beatificación de Hipólita. Santa Sabina, Roma; Signatura: X. 1377b. Proceso de beatificación de Hipólita de Jesús; Signatura: X.1377a. 1676. Congregatione Sacrorum Rituum sive Eminentissimo, ac Reverendissimo card. Portocarrero, Roma.

Ahumada, L. de. 2013. «Hipólita de Jesús. Biografía y bibliografía» en R. Ma. Alabrús (ed.): La vida cotidiana y la sociabilidad de los dominicos: 133-148. Sant Cugat: Editorial Arpegio.

Alabrús, R. Ma. 2013: «Misiones en Japón. Las órdenes religiosas ante los martirios en los siglos XVI y XVII» en R. Ma. Alabrús (ed.): La vida cotidiana y la sociabilidad de los dominicos: 237-262. Sant Cugat: Editorial Arpegio

AMA (Archivo del Monasterio de los Ángeles, Sant Cugat). Rocabertí, J. T. de (ed.). 1679. La Venerable Madre Hipólita de Jesús y Rocabertí. Valencia: Imprenta Francisco Mestre; Signatura: 1/01/19, Libro 1 del manuscrito: La vida de sor Hipólita de Rocabertí. Mercedes que Dios le hizo; Signatura: 01/18D. 1671. Proceso diocesano de beatificación de Hipólita de Jesús.

Andrés, M. 1994. Historia de la mística de la Edad de Oro, en España y América. Madrid: BAC.

Bernard, Ch. A. 2006. Teología mística. Burgos: Monte Carmelo.

\footnotetext{
${ }^{57}$ Callado, E. 2011. «El inquisidor general Rocabertí» en R. Ma. Alabrús. Tradición y modernidad. El pensamiento de los dominicos en la Corona de Aragón en los siglos xVII y XVIII: 79-94, Madrid: Silex; 2012. «Historia y glorias dominicanas en la obra editorial de fray Juan Tomás de Rocabertí» en R. Ma. Alabrús (coord.): La memoria escrita de los dominicos: 59-86, Sant Cugat: Arpegio.
} 
BUB (Biblioteca Universitaria de Barcelona). Rocabertí, J. T. de (ed.). 1679. La Venerable Madre Hipólita de Jesús y Rocabertí. Valencia: Imprenta Vicente Cabrera; 1660. Hipólita. La explicación de la Regla de San Agustín y otros varios tratados espirituales en Tomo III de las obras espirituales de la Venerable. Valencia.

BUB (Biblioteca Universitaria de Barcelona). 1672. Breve ristretto della vita maravigliosa e delle virtú mirabili della venerabile madre e serva di Dio Suor Ippolita di Giesu, nel secolo chiamta D. Isabella de Roccaberti, monaca dell'ordine di S. Domenico nel religiosissimo monastero degl' Angeli della città di Barcellona/composto da un religioso del medesimo ordine. Roma.

Busquets Matoses, J. 1684. Las cinco piedras de David. Valencia.

Callado, E. 2011. «El inquisidor general Rocabertí» en R. Ma. Alabrús. Tradición y modernidad. El pensamiento de los dominicos en la Corona de Aragón en los siglos XVII y XVIII. Madrid: Silex; 2012. «Historia y glorias dominicanas en la obra editorial de fray Juan Tomás de Rocabertí» en R. Ma. Alabrús (coord.): La memoria escrita de los dominicos. Sant Cugat: Arpegio.

Callado, E. 2011. Sin pecado concebida. Valencia y la Inmaculada en el siglo XVII. Valencia: Institució Alfons el Magnànim.

Callado, E. 2007. Por Dios y por el rey. El Inquisidor Fray Juan Tomás de Rocabertí. Valencia: Institució Alfons el Magnànim.

Caro Baroja, J. 1978. Las formas complejas de la vida religiosa: religión, sociedad y carácter en la España de los siglos XVI y XVII. Madrid: Galaxia Gutenberg.

Feros, A. y Gelabert, J. (dirs) 2004: España en tiempos del Quijote. Madrid: Ed. Asociación de Estudios de Ciencias Sociales y Humanidades.

Garganta, J. Ma. O.P. 1981. «Un capítol gironí d'Història espiritual» en Annals de l'Institut d'Estudis Gironins 25,2: 133-144

Garrigou-Lagrange, R. OP. 1944. Las tres edades de la vida interior. Buenos Aires: Ed. Desclée, de Brouwer.

Giordano, L. 2011. «La Contrarreforma y sus críticos. Biblia y oración mental en Hipólita de Rocabertí» en R. Ma. Alabrús: Tradición y modernidad. El pensamiento de los dominicos en la Corona de Aragón en los siglos XVII y XVIII: 17-52. Madrid: Sílex; 2012. «Memoria y tradición en la dominica catalana Hipólita de Jesús» en R. Ma.Alabrús (coord): La memoria escrita de los dominicos: 177-198. Sant Cugat: Editorial Arpegio.

González-Arintero, J. OP. 1980. La verdadera mística tradicional. Salamanca: Editorial Fides, $2^{\mathrm{a}}$ Ed.

Gras Casanovas, Ma. M. 2013. «Familia y clausura. El monasterio de Nuestra Señora de los Ángeles y Pie de la Cruz de Barcelona (1485-1750)» en R. Ma. Alabrús: La vida cotidiana y la sociabilidad de los dominicos: 117-148. Sant Cugat: Editorial Arpegio; Gras Casanovas, Ma. M. 2013. «L'escriptura en el Carmel descalç femení: la província de Sant Josep de Catalunya (1588-1835), Scripta, Revista internacional de literatura i cultura medieval i moderna 1: 302-322. Universidad de Barcelona. 
Imirizaldu, J. 1977. Monjas y beatas embaucadoras. Madrid: Editora Nacional.

Kagan, R. 1991. Los sueños de Lucrecia. Delitos y porfecías en la España del siglo XVI. Madrid: Editorial Nerea.

Lorea, A. de. 1679. La Venerable Hipólita de Jesús y Rocabertí. Sacado de los procesos de su beatificación y canonización y otros instrumentos auténticos. Valencia: Vicente Cabrera impresor.

Lorenzo Villanueva, J. 1791. De la lección de la Sagrada Escritura en lenguas vulgares: LXXXVIII-IX, Madrid.

Pilo, R. 2010. Juan Everardo Nithard y sus causas no causas. Razones y pretextos para el fin de un valimiento. Madrid: Sílex.

Poutrin, I. 1995. Le voile et la plume. Autobiographie et sainteté femenine dans l'Espagne moderne. Madrid: Bibliothèque de la Casa de Velázquez.

Puig, J. 1624. Sermón que predicó el padre Jaime Puig rector de la Compañía de Jesús en las honras que hizo el monasterio de nuestra señora de los Ángeles a la Venerable sor Hipólita de Rocabertí y Soler. Barcelona

Rocabertí, H. de. 1608. Relación hecha por la madre sor Hipólita de Jesús, subpriora del convento de religiosas dominicas de nuestra señora de los Ángeles, a la muerte de Estefanía de Rocabertí. Barcelona.

Rocabertí, H. de. 1660. Tomo III de las Obras espirituales de la Venerable madre Hipólita de Jesús y Rocabertí. Contiene la explicación de la Regla de San Agustín, Valencia

Rocabertí, H. de. 1679. La Venerable madre Hipólita de Jesús y Rocabertí. Libro primero de su admirable vida y doctrina que escribió de su mano. Valencia.

Rocabertí, J. T. de. 1669. Theología mística, primer tomo. Instrucción del alma en la oración y meditación. Barcelona.

Sánchez Lora, J. 1988. Mujeres, conventos y formas de religiosidad barroca. Madrid: Fundación Universitaria Española.

Serrano y Sanz, M. 1975. Apuntes para una biblioteca de escritoras españolas desde 1401 a 1833. Madrid: Atlas, 2 vols, reed.

Teresa de Jesús. 1951. Obras completas de Teresa de Jesús I, Vida. Madrid.

Vallgornera, T. de. 1662. Mystica Theologia D. Thomae, Utriusque theologiae scolasticae et misticae principis. Barcelona

Vilanova, E. 1986. Història de la teologia cristiana, vol II. Pre-reforma, reformes, contrarreforma. Barcelona: Facultad de Teología de Cataluña-Editorial Herder.

Vilar, P. 1964. «El tiempo del Quijote» en Crecimiento y desarrollo. Barcelona: Ariel. 